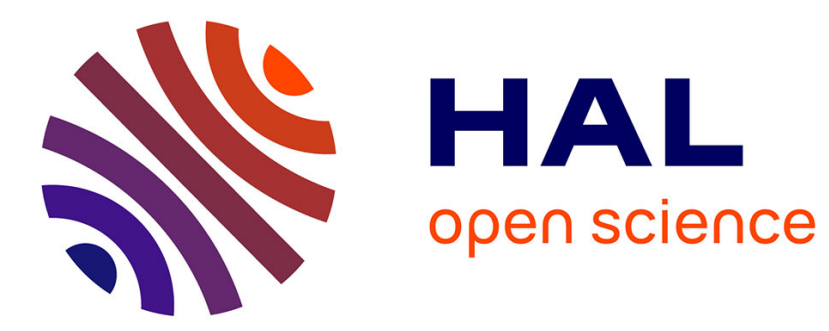

\title{
Foot-and-mouth disease virus infection in young lambs: Pathogenesis and tissue tropism
}

Eoin Ryan, Jacquelyn Horsington, Stephanie Durand, Harriet Brooks, Soren Alexandersen, Joe Brownlie, Zhidong Zhang

\section{- To cite this version:}

Eoin Ryan, Jacquelyn Horsington, Stephanie Durand, Harriet Brooks, Soren Alexandersen, et al.. Foot-and-mouth disease virus infection in young lambs: Pathogenesis and tissue tropism. Veterinary Microbiology, 2008, 127 (3-4), pp.258. 10.1016/j.vetmic.2007.08.029 . hal-00532314

\section{HAL Id: hal-00532314 https://hal.science/hal-00532314}

Submitted on 4 Nov 2010

HAL is a multi-disciplinary open access archive for the deposit and dissemination of scientific research documents, whether they are published or not. The documents may come from teaching and research institutions in France or abroad, or from public or private research centers.
L'archive ouverte pluridisciplinaire HAL, est destinée au dépôt et à la diffusion de documents scientifiques de niveau recherche, publiés ou non, émanant des établissements d'enseignement et de recherche français ou étrangers, des laboratoires publics ou privés. 


\section{Accepted Manuscript}

Title: Foot-and-mouth disease virus infection in young lambs:

Pathogenesis and tissue tropism

Authors: Eoin Ryan, Jacquelyn Horsington, Stephanie

Durand, Harriet Brooks, Soren Alexandersen, Joe Brownlie,

Zhidong Zhang

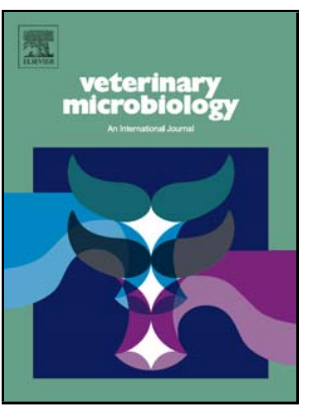

PII:

S0378-1135(07)00432-4

DOI:

doi:10.1016/j.vetmic.2007.08.029

Reference:

VETMIC 3809

To appear in: $\quad$ VETMIC

Received date: 24-4-2007

Revised date: 23-8-2007

Accepted date: $\quad 24-8-2007$

Please cite this article as: Ryan, E., Horsington, J., Durand, S., Brooks, H., Alexandersen, S., Brownlie, J., Zhang, Z., Foot-and-mouth disease virus infection in young lambs: Pathogenesis and tissue tropism, Veterinary Microbiology (2007), doi:10.1016/j.vetmic.2007.08.029

This is a PDF file of an unedited manuscript that has been accepted for publication. As a service to our customers we are providing this early version of the manuscript. The manuscript will undergo copyediting, typesetting, and review of the resulting proof before it is published in its final form. Please note that during the production process errors may be discovered which could affect the content, and all legal disclaimers that apply to the journal pertain. 
1 Foot-and-mouth disease virus infection in young lambs: pathogenesis and tissue

\section{2 tropism}

3

4 Eoin Ryan ${ }^{\mathrm{a}, \mathrm{b}}$, Jacquelyn Horsington ${ }^{\mathrm{a}}$, Stephanie Durand ${ }^{\mathrm{a}}$, Harriet Brooks ${ }^{\mathrm{b}}$, Soren $5 \quad$ Alexandersen ${ }^{\mathrm{c}}$, Joe Brownlie ${ }^{\mathrm{b}}$, Zhidong Zhang ${ }^{\mathrm{a} *}$.

6

7 a Institute for Animal Health, Pirbright Laboratory, Ash Road, Pirbright, Woking, 8 GU24 0NF, UK.

9 boyal Veterinary College, Hawkshead Lane, North Mymms, Hatfield, AL9 7TA, 10 UK.

$11^{c}$ National Veterinary Institute, Danish Technical University, Lindholm, DK-4771 12 Kalvehave, Denmark

13

14 *Correspondence to Zhidong Zhang, Institute for Animal Health, Pirbright 15 Laboratory, Ash Road, Pirbright, Woking, GU24 0NF, UK.

16 Email Zhidong.Zhang@bbsrc.ac.uk; phone +44 (0)1483 231135; fax +44 (0)1483 17232448. 
19

20

21 Foot-and-mouth disease (FMD) in adult sheep usually causes milder clinical signs

\section{Abstract}

than in cattle or pigs, and is often subtle enough to go undiagnosed. In contrast, FMD in lambs has been reported to cause high mortality during field outbreaks. In order to investigate the pathogenesis of FMD in lambs, two groups, aged 10-14 days, were infected with foot-and-mouth disease virus (FMDV) type O UKG. One group of lambs $(n=8)$ was inoculated with FMDV in the coronary band, while the other $(n=4)$ was infected by direct contact with FMDV-inoculated ewes. Daily serum samples and temperature measurements were taken. Lambs were killed sequentially and tissue samples taken for analysis. Using real-time RT-PCR, viral RNA levels in tissue samples and serum were measured, and a novel strand-specific real-time RT-PCR assay was used to quantify viral replication levels in tissues. Tissue sections were examined for histopathological lesions, and in situ hybridisation (ISH) was used to localise viral RNA within histological sections. The contact-infected lambs became infected approximately 24 hours after the ewes were inoculated. Vesicular lesions developed on the feet of all lambs and on the caudo-lateral part of the tongues of 6 of the 8 inoculated lambs and 3 of the 4 contact-infected lambs. Although no lambs developed severe clinical signs, one of the contact-infected lambs died acutely at 5 days post-exposure. Histological examination of the heart from this lamb showed multi-focal areas of lymphocytic-plasmacytic myocarditis; similar lesions were also observed in the hearts of three of the inoculated lambs. Using ISH, viral RNA was localised within cardiac and skeletal muscle cells from the lamb which had died, and also from vesicular lesions on the coronary band and tongue of inoculated lambs. 
43 These results provide a detailed description of the pathogenesis of the disease in 44 lambs.

45 Keywords: foot-and-mouth disease virus; sheep; lamb; pathogenesis; in situ 46 hybridisation

47

48 


\section{INTRODUCTION}

Foot-and-mouth disease (FMD) is a highly contagious acute vesicular disease of cloven-hoofed animals. The aetiological agent, foot-and-mouth disease virus (FMDV), is classified with the Aphthovirus genus as a member of the Picornaviridae family (Belsham, 1993). FMD is an economically devastating disease, causing significant production losses in infected domestic livestock. As a result, it is a major hindrance to international trade in animals and animal products. The cost of an outbreak can be enormous; the 2001 outbreak in the UK is estimated to have cost the agricultural sector $£ 3.1$ billion, with similar losses to the tourism sector (Thompson et al., 2002).

Clinical signs are generally milder in sheep than in cattle or pigs. Viraemia may be present for up to 3 days before the appearance of vesicular lesions (Alexandersen et al., 2003). During this time the sheep may be pyrexic and distressed with lameness spreading through the flock. Agalactia may occur in ewes. Vesicular lesions occur in the interdigital cleft, along the coronary bands and on the bulb of the heels. Oral lesions are less common but can occur on the dental pad, tongue and gums (Hughes et al., 2002). In pregnant sheep, transplacental infection of the foetal lamb may occur, causing abortion (Ryan et al., 2007).

Young lambs may die acutely following infection; associated clinical signs include collapse, fever, tachycardia and marked abdominal respiration (Garcia-Mata et al., 1954;1955; Geering, 1967; Pay, 1988). Deaths in lambs start to occur two to three days after the appearance of clinical signs in the ewes, and are usually reported to be 
74 the result of heart failure or starvation; post-mortem lesions include myocarditis, 75 septicaemia, abomasitis and enteritis (Littlejohn, 1970; Salyi 1939). Reported mortality rates vary widely, from $4.7 \%$ in an outbreak in India (Panisup et al., 1979) to $94.5 \%$ in lambs of two to 25 days old in a Russian outbreak (Khankishiev et al., 1958). Neonatal lamb deaths were reported in Dumfries during the 2001 outbreak in the UK (Reid, 2002). A PanAsia type O virus strain was reported to have caused large-scale lamb mortality in Iraq (Knowles and Samuel, 2003).

Mortality among FMD-infected calves and pigs has also been described. Death may occur without vesicular lesions due to the peracute onset of FMD in these animals. Pale foci of myocardial necrosis are seen in the ventricular wall and papillary muscle, referred to as "tiger heart" due to striping effect (Jubb, 1993). Donaldson et al. (1984) reported that the majority of piglets infected with an $\mathrm{O}_{1}$ Lausanne strain died or became moribund and were killed without developing vesicles. The deaths of the piglets started before clinical disease was evident in the sows. Macroscopic "tiger heart" lesions were not observed in any piglet hearts, although in all but one, myocarditis was present on histopathological examination.

Despite the numerous reports of FMD-related deaths in lambs, there is little data available on FMDV tropism or quantitative aspects of viral RNA kinetics in neonatal lambs, which would help understand the reasons for this high mortality and the influence of maternal infection on young lambs. In this study, viral distribution, tissue tropism and associated pathology during the acute stages of FMD were investigated in neonatal lambs experimentally infected with FMDV O UKG. 
99

100

101

102

103

104

105

106

107

108

110

111

112

113

114

115

116

117

118

119

120

121

123

MATERIALS AND METHODS

\section{Inoculum}

The FMDV strain used was O UKG 34/2001, isolated from a pig at Cheale Meats Abattoir, Essex on 20 February 2001 (Alexandersen and Donaldson, 2002). The inoculum was the second pig passage of original pig epithelial tissue suspension.

\section{Animal experiments}

Animals were housed in a category 4 bio-containment animal unit (Specified Animal Pathogens Order, DEFRA 1998). Animal experimentation was carried out in accordance with the UK Animals (Scientific Procedures) Act 1986 and associated guidelines. Two separate experiments were carried out. The first involved inoculating ewes and allowing their lambs to become infected by direct contact, simulating natural infection in the field. In the second experiment, lambs were inoculated directly.

Experiment 1: Ten lambs, 10-14 days old, and seven dams were used in this experiment, with ewes numbered VM76 to VM82. Lambs were assigned the same numbers as their dams, with the prefix LA for singletons or the first of a pair of twins, and LB for the second of a pair of twins, i.e. LA76 to LB82. Two lambs and a ewe were killed as negative controls before the inoculations were carried out. Eight lambs were inoculated with $10^{5.9}$ FMDV O UKG 34/2001 in the coronary band. Two were killed at 2, 4, 7, and $10 \mathrm{dpi}$, with the ewes being killed at the same timepoints as their offspring.

Experiment 2: Five ewes, each with a lamb of 10-14 days, were used in this experiment, with ewes numbered from VE37 to VE41. The lambs were assigned the same numbers as their ewes, with the prefix L, i.e. L37 to L41. Negative control samples of serum were taken from all animals and a ewe and lamb were killed as 
124

125

126

129

130

131

132

133

134

135

136

137

138

139

140

141

142

143

144

145

146

147

negative controls prior to inoculation. Four ewes were inoculated by coronary band inoculation with $10^{5.9} \mathrm{TCID}_{50}$ FMDV O UKG 34/2001. The ewes were housed in pens in direct contact with their lambs. One ewe and her lamb were killed at two, three and four days post-inoculation (dpi). The fourth infected lamb was found dead on the morning of day five post-inoculation. The mother of this lamb was killed on day seven.

\section{Sample collection}

Daily serum and nasal swab samples were collected from ewes and lambs and clinical signs and temperatures recorded. At post-mortem examination, various tissue samples were collected, as listed in Tables 1, 2, 4 and 5. Tissues collected from ewes included cervical and mandibular lymph nodes (LN), heart, liver, mammary gland, soft palate, spleen, tonsil, cotyledon, muscle (taken from lumbar area), tongue epithelium, uterus wall and coronary band skin (from non-inoculated coronary band). Tissues collected lambs included cervical and mandibular LNs, duodenal intestine, heart, kidney, liver, caudal lung lobe, muscle (from lumbar area), skin from lateral hindleg, soft palate, spleen, tongue, tonsil and coronary band skin (from non-inoculated coronary band). A portion of each tissue was put in RNAlater (Ambion, UK) for RNA extraction, and $10 \%$ formalin (formol-FIXX, Shandon, UK) for histological examination and in situ hybridisation as described below. Tissues were fixed in 10\% formalin for less than 24 hours and then placed in $1 \%$ formalin, followed by embedding in paraffin wax.

\section{RNA extraction}

For automated RNA extraction from serum samples, $200 \mu$ of sample was mixed with $300 \mu \mathrm{MagNa}$ Pure LC total nucleic acid lysis buffer (Roche, UK). Total nucleic 
148 acids were extracted and eluted in $50 \mu$ l elution buffer by using the MagNa Pure LC

149 total nucleic acid isolation kit (Roche,UK) with an automated robotic workstation

150 (Roche), according to manufacturer's instructions, as described by Quan et al. (2004).

151 For tissue samples, $20 \mathrm{mg}$ of tissue were homogenised by placing them in $700 \mu \mathrm{l}$ of

152 tissue lysis buffer (Roche, UK) in Lysing Matrix D tubes (Q-Biogene, UK) and

153 shaking them at 6,500 revolutions per minute for 45 seconds three times in a FastPrep

154 FP120 homogenising machine (Q-Biogene, UK). RNA was extracted and eluted in 50

$155 \mu$ l elution buffer by using the MagNa Pure LC RNA extraction kit III (Roche, UK)

156 with an automated robot as described above. Extracted RNA was stored at $-80^{\circ} \mathrm{C}$ until

157 used.

158 Real-time quantitative RT-PCR assay for detection of viral RNA.

159 The level of viral RNA in tissue, serum and amniotic fluid samples was quantified by 160 real-time RT-PCR as described previously (Reid et al., 2002), using a Taqman probe 161 specific for FMDV type O strain UKG 34/2001 as described previously (Quan et al., 162 2004). PCR assays were performed on a Stratagene MX4000 machine. For the 163 generation of standard curves, a FMDV RNA standard was synthesized in vitro from 164 a plasmid containing a 500 base pair insert of the internal ribosomal entry site (IRES) 165 of FMDV O UKG 34/2001 (kindly provided by Dr G. Belsham, Institute for Animal 166 Health, UK) using a MEGAScrip ${ }^{\mathrm{TM}} \mathrm{T} 7$ kit (Ambion, UK) as described previously 167 (Quan et al., 2004).

\section{Detection of antibody in sera by ELISA}

170 A liquid-phase blocking ELISA was used to titrate levels of anti-FMDV antibodies in 171 serum samples, as described previously (Ferris et al., 1990). 


\section{Analysis of FMDV replication in tissues using strand specific real-time RT-PCR}

174 In order to analyse viral replication levels in tissue samples, a strand specific real-time

175 RT-PCR was used as previously described (Horsington and Zhang, 2007)..A ratio of

176 positive to negative strands was calculated based on the quantification of levels of

177 positive and negative sense viral RNA transcripts in tissues. This ratio gives an

178 indication of the degree of viral replication in a sample, with a lower ratio indicating a

179 higher level of replication. Briefly, a tagged forward primer was designed containing

180 a 20 nucleotide 'tag' sequence unrelated to FMDV at the 5' end with the rest of the

181 primer (20 bases) specific to the FMDV 3D negative strand. Similarly, a tagged

182 reverse primer was designed to target the FMDV 3D positive strand. cDNA was

183 produced using the Thermoscript (Invitrogen, UK) RT components. $6 \mu 1$ RNA was

184 combined with $1 \mu 1 \mathrm{dNTPs}, 0.3 \mu \mathrm{l}$ primer (Tag-3D7151F, $10 \mu \mathrm{M}$ or Tag-3D7251R,

$18510 \mu \mathrm{M})$ and $4.7 \mu 1 \mathrm{dH}_{2} \mathrm{O}$, and heated to $75^{\circ} \mathrm{C}$ for 2 minutes. The reactions were then

186 placed on ice for 2 minutes. $4 \mu 15 \mathrm{X}$ cDNA synthesis buffer, $1 \mu 10.1 \mathrm{M}$ DTT, $1 \mu 1$

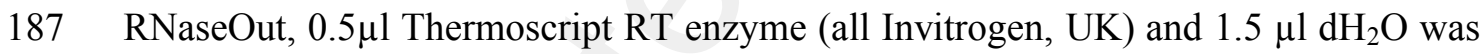

188 combined and added to the samples. Reverse transcription was performed at $62^{\circ} \mathrm{C}$ for

18935 minutes followed by 10 minutes at $95^{\circ} \mathrm{C}$. Real-time quantitative PCR was

190 performed using TAG/3D7251R primers for the negative strand assay and

191 3D7151F/TAG primers for the positive strand assay and a FAM-TAMRA probe,

192 3D7196P, on the Stratagene 3005P real-time PCR machine (Stratagene, UK). $5 \mu 1$

193 cDNA was combined with $12.5 \mu 1$ 2x Taqman Mastermix (Applied Biosystems, UK),

$1941 \mu \mathrm{l}$ each of the forward and reverse primer $(10 \mu \mathrm{M}), 0.5 \mu 1$ probe $(5 \mu \mathrm{M})$ and $\mathrm{dH}_{2} \mathrm{O}$ to

$19525 \mu 1$. The program comprised of 2 minutes at $50^{\circ} \mathrm{C}, 10$ minutes at $95^{\circ} \mathrm{C}$, and 50 cycles

196 of $95^{\circ} \mathrm{C}$ for 15 seconds and $58^{\circ} \mathrm{C}$ for 1 minute. The standard curve was derived from 
197 synthetic negative or positive strand FMDV transcripts from $1 \times 10^{8}$ to $1 \times 10^{1}$

198 copies/ $\mu 1$.

199 In situ hybridisation

200 RNA probes and labelling

201 A plasmid containing a part of the 3D region of FMDV type O UKG 34/2001 was 202 made and cells transfected with this plasmid kindly supplied by Nicholas Juleff, 203 Institute for Animal Health. The negative-sense RNA probe, complementary to the 204 positive-sense RNA of FMDV, generated from this plasmid was used on tissues from 205 experiment 1 (lambs LA76-LB82). A plasmid containing a part of the 3D region of 206 the FMDV type O Kaufbeuren strain genome (kindly provided by Dr G. Belsham, 207 Institute for Animal Health) was used to generate probe for use on tissues collected 208 from experiment 2 (lambs L37-L41). A plasmid containing part of the SVDV genome 209 was used to generate a control ISH probe.

210 The plasmids were linearised and then purified using phenol/chloroform extraction.

211 The RNA probes were synthesised from plasmid DNA and labelled with digoxenin 212 using a DIG RNA SP6/T7 labelling kit (Roche, UK) according to the manufacturer's 213 instructions.

\section{Hybridisation}

215 An mRNAlocator ${ }^{\mathrm{tm}}$ In situ hybridisation kit (Ambion, UK) was used to localise

216 FMDV in tissues. Sections $(4 \mu \mathrm{m})$ of the paraffin wax-embedded samples of fixed 217 tissues were applied to superfrost microscope slides (BDH, UK). They were incubated 218 at $56^{\circ} \mathrm{C}$ for 20 minutes to melt the paraffin, then put in xylene (BDH, UK) for $2 \times 15$ 219 minutes at room temperature to dewax. The sections were put in $100 \%$ ethanol for 
220

221

$2 \times 10$ minutes, then 5 minutes each in $90 \%, 70 \%$ and $50 \%$ ethanol, followed by 5 minutes in phosphate buffered saline (PBS). Sections were immersed in $0.05 \%$ proteinase $\mathrm{K}(70 \mathrm{U} / \mu \mathrm{l})$ in PBS for 10 minutes at room temperature then rinsed in nuclease-free water. Sections were then placed in a solution of $1.32 \%$ triethanolamine and $0.5 \% \mathrm{HCl}$ (Sigma, UK) in nuclease-free water for 3 minutes at room temperature, followed by 10 minutes incubation in a solution of $1.32 \%$ triethanolamine, $0.5 \% \mathrm{HCl}$ and $0.24 \%$ acetic anhydride in nuclease-free water at room temperature. Slides were washed for 5 minutes in PBS and placed in $100 \%$ ethanol for 5 minutes, then air dried.

Hybridisation cover chambers (Sigma, UK) were applied to slides and overlaid with $40 \mu \mathrm{l}$ prehybridisation buffer, followed by incubation in a humid chamber at $60^{\circ} \mathrm{C}$ for one hour. Hybridisation solution was prepared by adding $1 \mu \mathrm{lof} 100 \mathrm{ng} / \mu \mathrm{l}$ probe to $40 \mu \mathrm{l}$ of hybridisation buffer for each section. Each slide had two sections on it, allowing one section to be overlaid with FMDV probe and the other with SVDV probe as a negative control. Prehybridisation buffer was removed from the chambers, then $40 \mu$ hybridisation solution added to each chamber. Slides were put on a hot plate at $65^{\circ} \mathrm{C}$ for 5 minutes, then incubated in a humid chamber at $60^{\circ} \mathrm{C}$ overnight.

The following morning, coverslips were removed and sections were washed in $2 \mathrm{x}$ saline-sodium citrate (SSC) for 30 minutes at $50^{\circ} \mathrm{C}$, then $1 \mathrm{x}$ SSC for 30 minutes at $50^{\circ} \mathrm{C}$. The slides were treated with $0.045 \%$ RNAse A $(450 \mathrm{U} / \mathrm{ml})$ in $1 \mathrm{x}$ RNAse digestion buffer for 30 minutes at $37^{\circ} \mathrm{C}$, then washed in $2 \mathrm{x}$ SSC for 30 minutes at $37^{\circ} \mathrm{C}$. Slides were incubated in a blocking solution of $0.1 \%$ Triton X-100 (Sigma, UK) and 2\% normal sheep serum (Vector Laboratories, UK) in $100 \mathrm{mM}$ Tris $\mathrm{HCl}(\mathrm{pH} 7.5)$ 
$245(\mathrm{BDH}, \mathrm{UK})$ and $150 \mathrm{mM} \mathrm{NaCl}(\mathrm{BDH}, \mathrm{UK})$ for 30 minutes at room temperature in a 246 humid chamber. Following this, sections were incubated for 1 hour at room 247 temperature in a humid chamber in an antibody solution of $0.1 \%$ anti-digoxenin 248 alkaline phosphatise sheep antibody (concentration $0.75 \mathrm{U} / \mu \mathrm{l})$ (Roche, UK), 0.05\% 249 Triton-X 100 and 1\% normal sheep serum in $100 \mathrm{mM}$ Tris $\mathrm{HCl}(\mathrm{pH} 7.5)$ and $150 \mathrm{mM}$ $250 \mathrm{NaCl}$.

252 Sections were then washed for $2 \times 30$ minutes in blocking solution with a gentle 253 shaker. They were incubated for 1 minute in a colouration buffer of $100 \mathrm{mM}$ Tris- $\mathrm{HCl}$ $254(\mathrm{pH} 9,5), 100 \mathrm{mM} \mathrm{NaCl}$ and $50 \mathrm{mM} \mathrm{MgCl}_{2}$. A colour solution of $0.35 \%$ 5-bromo, 4255 chloro, 3-indolylphosphate (BCIP) (Boehringer Mannheim, Germany) and 0.45\% 256 nitroblue tetrazolium (NBT) (Boehringer Mannheim, Germany) was added to the 257 colouration buffer and slides were incubated in this in a humid chamber for 1 hour. A 258 water wash stopped colouration. Slides were counterstained with methyl green 259 (Vektor Laboratories, Inc., USA) for 2 minutes 30 seconds at $60^{\circ} \mathrm{C}$ on heat block, 260 dipped in water, then mounted with Immumount (Thermoshandon Electron 261 Corporation, UK).

\section{RESULTS}

\section{Kinetics of viral RNA in ewes experimentally infected with FMDV}

266 All inoculated ewes developed signs of clinical signs of FMD within 1-2 dpi. The 267 kinetics of viral RNA in serum samples are shown in Fig. 1 with daily temperature 268 data. All inoculated ewes developed viraemia at 1 dpi (average $9.6 \log _{10}$ copies per $\mathrm{ml}$ ). Viral RNA levels then peaked at 2 dpi (average $10 \log _{10}$ copies per $\mathrm{ml}$ ). The 
270 tissue distribution of viral RNA in samples taken at post-mortem examination is 271 summarised in Table 1.

272

273 Ewes infected by direct contact with inoculated lambs developed viraemia from 2 to 3

274 days post inoculation of lambs, and this viraemia peaked at 3 dpi (average $7.5 \log _{10}$

275 copies per ml). Ewe VM76 (killed 2 dpi) did not develop viraemia, although viral 276 RNA was detected in four of the tissue samples from this sheep. Levels of viral RNA 277 in serum samples from these ewes are shown in Fig. 2, along with graphs of body 278 temperature illustrating pyrexia. The level of viral RNA in tissue samples collected at 279 post-mortem examination is summarised in Table 2.

\section{Clinical signs and gross lesions in lambs experimentally infected with FMDV}

282 All inoculated lambs had early-stage vesicles on the coronary band at 1 dpi. By the 283 following day, all had fully-developed pedal vesicles; one lamb (LB78) had lesions on 284 four feet, two had lesions only at the inoculation site (LA78 and LA81), while the 285 others had two lesions each on their coronary bands. By 3 dpi, all lambs had at least 286 three pedal lesions, and lamb LA80 had a lesion on its dental pad. Only lamb LA79 287 (killed at 2 dpi) had been lame. On day 4, most lesions had ruptured and were starting 288 to crust over; the following day, all lesions had begun to heal. By $7 \mathrm{dpi}$, the lesions on 289 the remaining four lambs had healed. At post-mortem examination, vesicles were 290 found on the lateral surfaces of the tongues at the level of the molars from one lamb at 2912 dpi, and all lambs at 4 and 7 dpi. At 10 dpi, a healing lesion was seen on the lateral 292 tongue of one lamb. Daily temperature measurements for the lambs are shown in Fig. 2933. 
295 In lambs infected by direct contact, early lesions were observed in lambs from around 2963 dpi. At post-mortem examination, lamb L40 (killed 3 dpi) had small vesicles on all 297 four feet, an erosive lesion on the lateral side of the tongue at the level of the molars, 298 and enlarged tonsils and cervical lymph nodes (CLN). Lamb L41 (killed 4 dpi) had 299 small vesicles on all four feet and a small erosion on the lateral surface of the tongue, 300 again at the level of the molars. It also had CLN enlargement. Lamb L38, which was

301 found dead on day 5, had vesicles on both fore-feet and three erosions on the tongue, 302 one on each lateral surface at the level of the molars and one on the dorsal surface of 303 the tongue. Daily temperature measurements for the lambs are shown in Fig. 4. It can 304 be seen that the three remaining lambs were pyrexic from 3 days after maternal 305 inoculation.

307 Kinetics of viral RNA in lamb serum during the acute stage of FMD

308 In inoculated lambs, levels of viral RNA in lamb serum samples, as measured by real309 time RT-PCR, are shown in Fig. 3. All lambs developed viraemia by 1 dpi. The 310 highest level was $10^{9.4}$ copies of viral RNA/ml serum, in lamb LA77 at 4 dpi. The 311 length of the viraemic period ranged from 2 days (lamb LA80) to 5 days (lamb 312 LB79).

314 In contact-infected lambs, viraemia was first detected at 2 dpi (Fig. 4) with serum 315 viral RNA levels peaking at 3 dpi. The levels of viral RNA detected in lamb serum at 3162 dpi ranged from $10^{8.7}$ to $10^{10.4}$ copies per ml. The highest level measured was $10^{11.1}$ 317 copies per ml, in lamb L38. By 4 dpi, no viral RNA was detected in the serum of lamb 318 L41, although no antibodies were detected in this serum sample. In contrast, lamb L38 319 still had a high level of viraemia at $4 \mathrm{dpi}$, with $10^{9.4}$ copies of viral RNA per ml. 
321 Antibody levels in serum from inoculated lambs

322 Antibody titres detected in lamb serum from inoculated lambs are summarised in

323 Table 3. No antibodies were detected in serum from the contact-infected lambs.

\section{Distribution and quantification of viral RNA in lamb tissues}

326 The distribution of viral RNA in tissues from inoculated lambs is summarised in 327 Table 4. Viral RNA was detected in all tissues at 2 and 4 dpi. At 2 dpi, the highest 328 levels were found in the coronary band, tongue, skin, tonsil and CLN. At 4 dpi, there 329 was more variation between tissues, with the highest levels in the coronary band, 330 heart, CLN, mandibular lymph node (MLN), tongue, and tonsil. At 7 dpi, no viral 331 RNA was detected in the liver, and there was less in the other tissues than at earlier 332 timepoints. The tongue was the only exception to this, with an average of $10^{11}$ 333 copies/g. Other tissues with the most viral RNA at this timepoint were the coronary 334 band and the CLN. By 10 dpi, there was no viral RNA detectable in 7 tissue samples

335 from one lamb and 3 from the other. The tonsil, with an average of $10^{10}$ copies $/ \mathrm{g}$, 336 contained the highest amount of viral RNA.

338 In contact-infected lambs, levels of viral RNA detected in lamb tissues are 339 summarised in Table 5. Viral RNA was evenly distributed throughout tissues 340 collected at 2 dpi from L39, with the highest levels in the coronary band, tongue, soft 341 palate, CLN, MLN and tonsil. At 3 dpi (L40), the highest level of viral RNA was 342 found in the skin of the foot, followed by the tongue, CLN, MLN and soft palate. The 343 lamb (L41) killed at 4 dpi had cleared the viraemia by the time it was killed although 344 antibody titration by ELISA on its serum at 4 dpi was negative. Most of the tissue 
345 samples contained low levels of viral RNA, and there was none detected in the heart.

346 Only the coronary band, tongue and tonsil contained $10^{8}$ copies of viral RNA or more

347 per gram. This is in marked contrast to the lamb (L38) found dead at $5 \mathrm{dpi}$, which had

348 a significant viraemia on days 2, 3 and 4 and had high levels of viral RNA in many

349 tissue samples, particularly the heart and skeletal muscle, which each contained over

$35010^{10}$ copies of viral RNA per gram.

351

352 Histopathology in the heart and muscle

353 Cardiac histopathological lesions in infected lambs are shown in Fig. 5. Multiple foci

354 of myocardial abnormalities were observed in sections from lamb LA81 (directly

355 inoculated with FMDV) at 4 dpi, including pale and ruptured myocardiocytes,

356 disordered myocardiocytes, aggregations of lymphocytes and oedema (Figs. 5a, 5b).

357 Similar lesions were observed in heart muscle from lambs LA80 (killed 7 dpi) and

358 LA78 (killed 10 dpi). In sections of heart from the contact-infected lamb found dead

359 on day five (L38) multi-focal myocardiocyte swelling, sometimes with hyalinisation,

360 and focally marked perivascular lymphocytic aggregation were described (Figs.5c,

$3615 \mathrm{~d})$. No significant histological abnormalities were recognised in sections of heart

362 from the other contact-infected lambs. In skeletal muscle sections from contact-

363 infected lamb L38, disordered myocytes with pale, foamy cytoplasm were recognised

364 histologically.

366 Localization of viral RNA in relation to histopathological lesions

367 ISH was carried out on tissue sections to localise viral RNA in relation to 368 histopathological lesions. In heart sections from the contact-infected lamb found dead 369 on day five (L38), viral RNA was distributed throughout the myocardium in a diffuse 
370

371

372

373

374

375

376

377

378

379

380

381

382

383

384

385

386

387

388

389

390

391

392

393

394

pattern, with positive signal found both in areas of cell swelling and in areas which were unremarkable in H\&E sections (Figs. 6a, 6b). The positive signal was found in the cytoplasm of the cells. No positive signal was observed in heart sections from the other contact-infected lambs. In addition, ISH on skeletal muscle sections from the same lamb also showed viral RNA distributed throughout the sections in a multi-focal array contrasting with the diffuse distribution seen in the myocardium (Figs. 6c, 6d).

No positive signal was found in the skeletal muscle sections from the other contactinfected lambs. ISH was also performed on skin, tongue, soft palate, lymph nodes and lung from all contact-infected lambs, but no positive signal was detected. Viral RNA was also localised within vesicles in sections of tongue and coronary band from inoculated lambs (Fig. 7). Positive signal can be seen within the lesions, deep to the stratum corneum and in the detached epithelium of the coronary band lesion, and diffusely throughout the two microvesicles in the stratum spinosum of the tongue.

\section{Analysis of viral replication levels in tissue samples using strand-specific real-} time RT-PCR assay

Using strand-specific real-time RT-PCR, the ratios of positive to negative viral RNA strands were calculated for each tissue sample from the lambs. Fig. 8(a) shows the ratios for each tissue for each inoculated lamb, while Fig. 8(b) shows the ratios for each tissue in contact-infected lambs. A lower ratio indicates active replication. Where no ratio is shown, no negative strand viral RNA was detected, indicating little or no replication was occurring in that tissue. Intermediate ratio levels are more difficult to interpret, as negative viral RNA transcripts may be drained to some areas via the lymphatic system or local circulation, without viral replication necessarily taking place in these sites. 
396 In the inoculated lambs at 2 dpi, negative strand viral RNA transcripts were detected 397 in most tissues. In the heart and muscle samples negative strand RNA was only 398 detected in samples from LA76, while negative strand RNA was only detected in the 399 liver in the sample from LA79; the ratio in these tissues was high. In all other tissues, 400 the ratio at 2 dpi was 100 or less. At 4 dpi, negative viral RNA strands were detected 401 in both lambs in the CB, CLN, MLN, spleen, tongue and tonsil, while negative 402 strands in the heart, kidney and skin were detected only in LA81. Only the intestine of 403 LA77 had detectable negative strand RNA. No replication was detected in the liver, 404 lung, muscle or soft palate at 4 dpi. At 7 dpi, negative viral RNA strands were 405 detected in the CB and tongue of both lambs, in the CLN of LA80 and in the kidney 406 and tonsil of LB79. Viral replication was not evident in other tissues at 7 dpi. At 10 407 dpi, negative viral RNA transcripts were detected in the tonsil of both lambs and the 408 soft palate of LB78 (Fig. 8a).

409

410 In the contact-infected lambs, only the CLN, MLN, tongue and tonsil had detectable 411 negative strand viral RNA at 2 days post maternal inoculation (lamb L39). The ratio 412 in the CLN was 11 , while the other three ratios ranged from 416 to 1542 . At 3 dpi, the $413 \mathrm{CB}$, tongue, CLN and MLN had detectable negative strand viral RNA, with the lowest 414 ratio in the tongue (ratio 33) (lamb L40). At 4 dpi, lamb L41 had detectable negative 415 strand viral RNA in the CB, tongue, tonsil and CLN, with the lowest ratio (45) in the 416 tongue. Lamb L38, found dead at 5 dpi, had detectable negative strand viral RNA in 417 every tissue except the liver and muscle. The ratios in the soft palate and tonsil were 7 418 and 6, respectively (Fig. 8b). 


\section{DISCUSSION}

420

421 The experiments described here characterised the pathogenesis and development of

422 FMD in neonatal lambs infected with FMDV. The viral RNA levels in serum and in

423 tissues samples were quantified, and viral replication levels in various tissues was

424 analysed by a novel negative strand RT-PCR assay. Importantly, viral RNA was

425 localised in cardiac and skeletal muscle cells from a lamb which died of FMD,

426 confirming the tropism of the virus for these tissues. The results provide a detailed

427 description of the pathogenesis of the disease in lambs.

429 All four contact-infected lambs developed viraemia from 2 dpi. From this it can be

430 deduced that the lambs became infected with FMDV approximately $24-36$ hours

431 after maternal inoculation. This allows time for the initial virus replication to occur in

432 the oropharynx, followed by dissemination to secondary sites of infection with

433 subsequent viraemia detectable at 2 dpi. Therefore, infecting lambs by contact with

434 inoculated ewes is likely to reflect the most common route of lamb infection in the

435 field during FMD outbreaks. Interestingly, the pattern of gross lesions on the tongue

436 in these lambs contrasts with that of older sheep and cattle, where lesions are more

437 common on the rostral tongue, gums and dental pad. It is thought that lesions are more

438 likely to develop at sites of trauma or intensive physical stress (Alexandersen et al.,

439 2003). When young lambs suckle the ewe, the sides of the tongue rub against the

440 molars whilst the dorsum of the tongue rubs against both the lower aspect of the teat

441 and the roof of the lamb's mouth. This may explain the difference in lesion

442 distribution. In the inoculated lambs, development of clinical signs appeared to be

443 more uniform than in the contact-infected lambs. Viraemia was present at $1 \mathrm{dpi}$ in all 
444 cases, with the level of viral RNA in serum ranging from $10^{6.6}$ to $10^{7.6}$ copies per ml.

445 The development of vesicles and onset of pyrexia was also similar in all inoculated 446 lambs. After 2 dpi, individual variation became apparent with the length of viraemia 447 varying from 2 days to 5 days. In inoculated lambs, lesions were observed on the 448 lateral aspects of the tongue at the levels of the molar teeth, as was observed in 449 contact-infected lambs. In contrast to contact infected lamb, however, no dorsal 450 tongue lesions were observed on any tongues from inoculated lambs. Furthermore, the 451 lingual lesions in contact-infected lambs appeared more severe than those in 452 inoculated lambs. This may be due to chance, but the route of infection may also have 453 influenced lesion location, as discussed above.

455 In investigating the kinetics of viraemia and viral RNA tissue distribution in lambs, 456 the results show that the acute-phase distribution of the virus is primarily to tissues 457 rich in epithelium such as the tongue and skin of the feet. Interestingly, the levels of 458 viral RNA found in tissue samples from inoculated lambs were generally much higher 459 than those in the contact-infected lambs. The highest level was in the coronary band at 4602 dpi $\left(10^{13.43}\right.$ copies/g) compared to a peak measurement of $10^{10.89}$ copies/g at $3 \mathrm{dpi}$ in 461 contact-infected lambs. These higher concentrations of viral RNA are most likely to 462 be due to the coronary band inoculation of the lambs. The initial high infectious dose 463 administered was followed by local replication and dissemination to distant secondary 464 sites of replication, with accompanying viraemia.

466 The histological appearance of sections of heart from the contact-infected lamb found 467 dead on day five (L38) included multiple scattered foci of myocardiocyte swelling, 468 occasionally with hyalinisation, with perivascular mononuclear aggregation (Fig. 5). 
469 The heart sections of the other contact-infected lambs had no significant histological 470 abnormalities. Histological abnormalities were evident in sections of the hearts of 471 inoculated lambs at 4 dpi (Fig. 5), and also at 7 and 10 dpi. In exploring if the 472 histological abnormalities observed in the heart is related to FMDV replication, 473 abundant viral RNA was detected by ISH in the heart and muscle of contact-infected 474 lamb L38, indicating that these tissues may act as sites of FMDV tropism in young 475 lambs.This is in agreement with similar work carried out in piglets (Donaldson et al., 476 1984). It supports the theory that neonatal mortality following FMDV infection may 477 be due to viral replication in the heart, providing a plausible explanation for the 478 dramatic death rates often reported in young animals during an outbreak. In contrast 479 to the results from contact-infected lambs, no positive signal was detected in any 480 muscle or heart sections from inoculated lambs, despite histological evidence of 481 cardiac abnormalities. This may be due to the deterioration of viral RNA in tissue 482 samples during processing. Such deterioration may also be a factor in the lack of 483 positive signal in tissue sections from 7 and $10 \mathrm{dpi}$, but a more important explanatory 484 reason may be the presence of antibodies at these time-points.

486 The ratios of positive to negative strand viral RNA transcripts in tissue samples from 487 the lambs provided an indication of the levels of viral replication in those tissues. 488 Although a low ratio is likely to indicate viral replication in a tissue and a high or zero 489 ratio indicates little or no replication, interpretation of intermediate values is more 490 difficult. Negative strand viral RNA may be drained to a tissue (e.g. lymph node) 491 from other areas without replication necessarily occurring in situ. Nevertheless, this 492 novel technique provides a degree of insight into FMDV replication which has not 493 previously been available. The results in the inoculated lambs show that over time, the 
494 number of sites of replication declined. Interestingly, by $10 \mathrm{dpi}$, the only tissues where

495 negative strand viral RNA transcripts were detected were the tonsil and soft palate.

496 The ratio in these tissues at 10 dpi was still quite low at around 100 , indicating a 497 degree of replication comparable to that in the epithelial tissues at 2 and 4 dpi. The 498 tonsil has previously been identified as the site of FMDV persistence in sheep 499 (Burrows, 1968), although it has also been suggested that the close association of the 500 ovine tonsil with the overlying palatine epithelium could explain this (Alexandersen et $501 a l ., 2003)$. Recent work in our laboratory has further supported this region as the site 502 of FMDV persistence in sheep (Horsington and Zhang, 2007). The low ratios found in 503 most tissues from inoculated lambs at 2 dpi show that, following inoculation with a 504 high dose of virus, negative strand viral RNA was detected at most sites in the body. 505 While replication might be expected at the recognised sites of viral replication such as 506 the coronary band, tongue, tonsil and soft palate, the low ratios in such tissues as the 507 kidney, intestine, heart, lung and spleen may indicate either viral replication at these 508 sites or negative strand viral RNA transported to these tissues via viraemic blood. In 509 the contact-infected group, viral replication occurred mainly in the epithelial tissues 510 and the CLN and MLN in the lambs killed at 2, 3 and 4 days after maternal 511 inoculation. This pattern is similar to that reported in other pathogenesis studies 512 (Burrows et al., 1981), and is in contrast to the inoculated lambs, which had a wider 513 distribution of negative strand viral RNA.

515 The results from the ewes are also significant (Tables 1 and 2). This is the first report 516 we are aware of in which FMDV RNA loads in adult sheep tissues have been 517 quantified at various time-points after infection using real-time RT-PCR. Although 518 lambs are unlikely to infect ewes in the field (the reverse situation being more 
519

520

probable), the data on transmission dynamics from inoculated lambs to in-contact ewes provides a useful insight into the acute pathogenesis of FMD in sheep following prolonged direct contact with infected cohorts. Viral RNA was first detected in two ewes (VM78 and VM80) at 2 dpi. At 3 dpi, viraemia was detected in one more sheep, while the remaining two became viraemic at 4 dpi. It is interesting that it took up to four days for infection to be detected in some ewes, despite being in continuous direct contact with their infected lambs. No viral RNA was detected in the serum of ewe VM76, an unexpected result given the detection of viral RNA in four tissue samples. It is likely that some viral RNA was present in the serum of this animal, but it may have been below the limit of detection. Alternatively, the serum sample from 2 dpi may have deteriorated during processing. By $10 \mathrm{dpi}$, the infection was waning and the levels of viral RNA were lower, probably due to antibody clearance. In conclusion, these studies of FMDV infection and replication in vivo provide a detailed description of the patterns of virus load and distribution in lambs. It is clear that quantitative analysis of viral load in vivo is a valuable tool in order to fully understand the pathogenic steps of FMDV infection.

\section{Acknowledgements}

We would like to thank Yanmin Li, Pip Hamblin and Caroline Wright for performing the antibody ELISAs and Nicholas Juleff for help with the ISH. We thank Colin Randall, Bev Standish and Malcolm Turner for their assistance with and handling of the animals. This work was funded by Defra, UK.

\section{References}


542

543

544

545

546

547

548

549

550

551

552

553

554

555

556

557

558

559

560

561

562

563

564

565

566

Alexandersen, S., Donaldson, A.I., 2002, Further studies to quantify the dose of natural aerosols of foot-and-mouth disease virus for pigs. Epidemiol. Infect. 128, 313-323.

Alexandersen, S., Zhang, Z., Donaldson, A.I., Garland, A.J.M., 2003, The pathogenesis and diagnosis of foot-and-mouth disease. J. Comp. Pathol. 129, 1-36.

Belsham, G.J., 1993, Distinctive features of foot-and-mouth disease virus, a member of the picornavirus family; aspects of virus protein synthesis, protein processing and structure. Prog. Biophys. Mol. Biol. 60, 241-260.

Burrows, R., 1968, The persistence of foot-and-mouth disease virus in sheep. Journal of Hygiene, Cambridge 66, 633-640.

Burrows, R., Mann, J.A., Garland, A.J., Greig, A., Goodridge, D., 1981, The pathogenesis of natural and simulated natural foot-and-mouth disease infection in cattle. J. Comp. Pathol. 91, 599-609.

Donaldson, A.I., Ferris, N.P., Wells, G.A., 1984, Experimental foot-and-mouth disease in fattening pigs, sows and piglets in relation to outbreaks in the field. Vet. Rec. 115, 509-512.

Ferris, N.P., Kitching, R.P., Oxtoby, J.M., Philpot, R.M., Rendle, R., 1990, Use of inactivated foot-and-mouth disease virus antigen in liquid-phase blocking ELISA. J. Virol. Methods 29, 33-41.

Garcia-Mata,E., Federer,K.E., Pizzi,I., Aramburu,H. G., 1954, Pathogenicity of foot and mouth disease virus in different species of unweaned animals. Rev-VetMilit. 2, 205-206.

Garcia-Mata,E., Federer,K.E., Pizzi,I., Aramburu,H. G., 1955, Pathogenicity of foot and mouth disease virus for new-born animals. Gac-vet. 17, 57-64. 
568 Geering, W., G., 1967, Foot and mouth disease in sheep. Aust. Vet. J.

569 Horsington, J., Zhang, Z., 2007, Analysis of foot-and-mouth disease virus replication $570 \quad$ using strand-specific quantitative RT-PCR. J. Virol. Methods, 144, 149-155.

571 Hughes, G.J., Mioulet, V., Kitching, R.P., Woolhouse, M.E., Alexandersen, S., 572 Donaldson, A.I., 2002, Foot-and-mouth disease virus infection of sheep: 573 implications for diagnosis and control. Vet. Rec. 150, 724-727.

574 Jubb, K.V.F., Kennedy, P.C., Palmer, N., 1993, Pathology of Domestic Animals, Vol 575 2, 4th Edition. Academic Press, Inc., Page 143. London, 143 p.

576 Khankishiev, A., M., Gadshiev, K., S., Alekperov, Y., G., 1958, Foot and Mouth 577 Disease in New-Born Lambs. Veterinariya, Moscow 35, 59-60.

578 Knowles, N.J., Samuel, A.R., 2003, Molecular epidemiology of foot-and-mouth 579 disease virus. Virus Res. 91, 65-80.

580 Littlejohn, A., 1970, FMD in sheep - part 1. State Veterinary Journal 25, 3-12.

581 Panisup, A., S., Kalra D, S., Chauhan H. V, S., 1979, Investigation of an outbreak of 582 FMD in sheep. Haryana Agricultural University Journal of Research 9, 111114.

584 Pay, T.W., F., 1988, FMD in sheep and goats: a review. FMD Bulletin 26, 2-13.

585 Quan, M., Murphy, C.M., Zhang, Z., Alexandersen, S., 2004, Determinants of early 586 foot-and-mouth disease virus dynamics in pigs. J. Comp. Pathol. 131, 294$587 \quad 307$.

588 Reid, H.W., 2002, FMD in a parturient sheep flock. Vet. Rec. 150, 791.

589 Reid, S.M., Ferris, N.P., Hutchings, G.H., Zhang, Z.D., Belsham, G.J., Alexandersen, 590 S., 2002, Detection of all seven serotypes of foot-and-mouth disease virus by 
real-time, fluorogenic reverse transcription polymerase chain reaction assay. J.

592 Virol. Methods 105, 67-80.

593 Ryan, E., Zhang, Z., Brooks, H.W., Horsington, J., Brownlie, J., 2007, Foot-and594 Mouth Disease Virus Crosses the Placenta and Causes Death in Fetal Lambs. J. Comp. Pathol. In Press.

596 Salyi, G., 1939, Myocarditis in Foot and Mouth Disease of Young Lambs. Allatorv597 Lapok. 62,159-160.

598 Thompson, D., Muriel, P., Russell, D., Osborne, P., Bromley, A., Rowland, M., 599 Creigh-Tyte, S., Brown, C., 2002, Economic costs of the foot and mouth 600 disease outbreak in the United Kingdom in 2001. Rev. Sci. Tech. Off. Int.

601 Epizoot. 21, 675-687.

602

603

604 
1 Table 1 Viral RNA in tissues from inoculated ewes.

\begin{tabular}{|lccccc|}
\hline \multirow{2}{*}{ dpi } & \multicolumn{5}{c|}{ Viral RNA load $^{\dagger}$} \\
\cline { 2 - 6 } Ewe ID & 0 & 2 & 3 & 4 & 7 \\
\hline Cervical LN & VE37* & VE39 & VE40 & VE41 & VE38 \\
Heart & 0 & 7.6 & 5.41 & 7.44 & 4.67 \\
Liver & 0 & 5.81 & 0 & 2.73 & 2.28 \\
Mammary gland & 0 & 7.09 & 6.77 & 0 & 0 \\
Mandibular LN & 0 & 7.74 & 7.06 & 7.26 & 6.68 \\
Muscle & 0 & 7.08 & 4.21 & 5.65 & 5.44 \\
Coronary band & 0 & 9.05 & 8.7 & 7.02 & 7.83 \\
Soft palate & 0 & 8.27 & 7.18 & 7.93 & 5.7 \\
Spleen & 0 & 7.82 & 6.17 & 6.32 & 4.7 \\
Tongue & 0 & 8.2 & 7.71 & 7.15 & 5.67 \\
Tonsil & 0 & 8.68 & 8.0 & 8.65 & 6.69 \\
Uterus & 0 & 7.9 & 7.52 & 5.08 & 4.28 \\
\hline
\end{tabular}

2
3

* uninfected ewe killed as a control and tissues collected for analysis.

$4 \uparrow$ viral RNA loads in tissues were quantified by real-time RT-PCR and expressed as $\log _{10}$ copy number

5 per $\mathrm{g}$ tissue

6 dpi: days post inoculation at the day the ewes were killed

7 LN: lymph node

8 
9 Table 2 Viral RNA in tissues from contact-infected ewes

\begin{tabular}{|lccccccc|}
\hline \multirow{2}{*}{ dpi } & \multicolumn{7}{c|}{ Viral RNA load $^{\dagger}$} \\
\cline { 2 - 7 } & 0 & 2 & 4 & 4 & 7 & 7 & 10 \\
\hline Ewe ID & VM82* & VM76 & VM77 & VM81 & VM79 & VM80 & VM78 \\
\hline Cervical LN & 0 & 7.19 & 11.46 & 9.68 & 10.15 & 8.23 & 7.86 \\
Cotyledon & 0 & 0 & 9.63 & 7.77 & 7.65 & 7.59 & 7.54 \\
Heart & 0 & 7.08 & 9.18 & 8.27 & 7.17 & 0 & 6.88 \\
Liver & 0 & 0 & 9.03 & 8.25 & 8.01 & 0 & 0 \\
Mandibular LN & 0 & 0 & 9.51 & 10.75 & 8.78 & 9.2 & 8.49 \\
Muscle & 0 & 0 & 8.78 & 7.9 & 8.43 & 7.48 & 6.31 \\
Coronary band & 0 & 0 & 8.77 & 10.45 & 9.57 & 11.2 & 8.79 \\
Soft palate & 0 & 0 & 8.39 & 9.67 & 9.53 & 8.15 & 7.25 \\
Tongue & 0 & 7.27 & 8.8 & 8.74 & 0 & 8.31 & 0 \\
Tonsil & 0 & 7.57 & 9.66 & 10.65 & 10.66 & 9.42 & 6.94 \\
\hline
\end{tabular}

10

$11 *$ uninfected ewe killed as a control and tissues collected for analysis.

$12 \dagger$ viral RNA loads in tissues were quantified by real-time RT-PCR and expressed as $\log _{10}$ copy number

13 per $\mathrm{g}$ tissue

14 dpi: days post lamb inoculation at the day the ewes were killed

15 LN: lymph node

16 
18 Table 3: Serum antibody titres from inoculated lambs, measured by ELISA.

19

20

\begin{tabular}{|c|c|c|c|c|c|c|c|c|c|c|c|}
\hline \multirow{2}{*}{$\begin{array}{l}\text { Lamb } \\
\text { no. }\end{array}$} & \multicolumn{11}{|c|}{ Antibody titre } \\
\hline & $0 \mathrm{dpi}$ & $1 \mathrm{dpi}$ & 2 dpi & $3 \mathrm{dpi}$ & 4 dpi & $5 \mathrm{dpi}$ & $6 \mathrm{dpi}$ & $7 \mathrm{dpi}$ & $8 \mathrm{dpi}$ & 9 dpi & $\begin{array}{l}10 \\
\text { dpi }\end{array}$ \\
\hline LA76 & 0 & 0 & 0 & & & & & & & & \\
\hline LA79 & 0 & 0 & 0 & & & & & & & & \\
\hline LA77 & 0 & 0 & 0 & 0 & 64 & & & & & & \\
\hline LA81 & 0 & 0 & 0 & 0 & 0 & & & & & & \\
\hline LB79 & 0 & 0 & 0 & 0 & 90 & 1448 & 724 & 1448 & & & \\
\hline LA80 & 0 & 0 & 0 & 0 & 90 & 256 & 362 & 1024 & & & \\
\hline LA78 & 0 & 0 & 0 & 0 & 0 & 1024 & 1024 & 724 & 1448 & 2896 & 1448 \\
\hline LB78 & 0 & 0 & 0 & 0 & 0 & 0 & 181 & 362 & 362 & 724 & 362 \\
\hline
\end{tabular}


21 Table 4 Viral RNA in tissues from inoculated lambs (expt. 1)

\begin{tabular}{|c|c|c|c|c|c|c|c|c|c|c|}
\hline \multirow[b]{2}{*}{ dpi } & \multicolumn{10}{|c|}{ Viral RNA load $^{\dagger}$} \\
\hline & 0 & 0 & 2 & 2 & 4 & 4 & 7 & 7 & 10 & 10 \\
\hline Lamb ID & LA82* & LB82* & LA76 & LA79 & LA77 & LA81 & LB79 & LA80 & LA78 & LB78 \\
\hline Coronary band & 0 & 0 & 13.43 & 12.41 & 10.39 & 13.09 & 10.19 & 10.35 & 0 & 8.43 \\
\hline Cervical LN & 0 & 0 & 11.25 & 9.85 & 9.77 & 9.59 & 7.79 & 9.52 & 8.18 & 9.12 \\
\hline Intestine & 0 & 0 & 9.26 & 10.37 & 7.72 & 7.93 & 6.53 & 6.08 & 0 & 0 \\
\hline Heart & 0 & 0 & 8.8 & 8.69 & 7.17 & 11.22 & 7.39 & 6.12 & 0 & 7.09 \\
\hline Kidney & 0 & 0 & 9.91 & 9.73 & 8.0 & 7.94 & 7.35 & 7.07 & 0 & 0 \\
\hline Liver & 0 & 0 & 8.93 & 8.56 & 6.23 & 7.42 & 0 & 0 & 0 & 6.04 \\
\hline Lung & 0 & 0 & 10.58 & 10.4 & 7.15 & 8.19 & 6.45 & 6.08 & 0 & 3.83 \\
\hline Mandibular LN & 0 & 0 & 9.97 & 10.02 & 9.52 & 10.28 & 8.45 & 7.51 & 8.66 & 8.55 \\
\hline Muscle & 0 & 0 & 9.22 & 8.08 & 7.51 & 7.55 & 8.75 & 7.45 & 0 & 0 \\
\hline Skin & 0 & 0 & 11.01 & 10.44 & 8.17 & 9.74 & 6.53 & 6.87 & 7.6 & 6.03 \\
\hline Soft palate & 0 & 0 & 10.02 & 9.78 & 7.27 & 7.51 & 7.02 & 6.69 & 7.04 & 9.87 \\
\hline Spleen & 0 & 0 & 9.93 & 9.61 & 9.1 & 9.27 & 7.46 & 7.41 & 7.88 & 8.12 \\
\hline Tongue & 0 & 0 & 11.87 & 10.24 & 9.62 & 10.17 & 10.74 & 11.26 & 7.09 & 7.35 \\
\hline Tonsil & 0 & 0 & 10.74 & 11.04 & 10.37 & 9.87 & 8.44 & 7.88 & 9.57 & 10.45 \\
\hline
\end{tabular}

* uninfected lambs killed as controls and tissues collected for analysis.

$24 \uparrow$ viral RNA loads in tissues were quantified by real-time RT-PCR and expressed as $\log _{10}$ copy number 25 per g tissue

26 dpi: days post inoculation at the day the lambs were killed

27 LN: lymph node 
29 Table 5 Viral RNA loads in tissues from contact-infected lambs (expt. 2)

7

\begin{tabular}{|lccccc|}
\hline \multirow{2}{*}{ dpi } & \multicolumn{5}{c|}{ Viral RNA load $^{\dagger}$} \\
\cline { 2 - 6 } & 0 & 2 & 3 & 4 & $5^{* *}$ \\
\hline Lamb ID & L37* & L39 & L40 & L41 & L38 \\
\hline Cervical LN & 0 & 7.82 & 7.7 & 7.17 & 7.62 \\
Heart & 0 & 7.58 & 6.36 & 0 & 10.3 \\
Liver & 0 & 6.5 & 7.02 & 0 & 5.99 \\
Mandibular LN & 0 & 8.79 & 7.74 & 6.97 & 8.69 \\
Muscle & 0 & 6.78 & 6.81 & 4.39 & 10.48 \\
Coronary band & 0 & 8.41 & 10.89 & 8.87 & 8.92 \\
Soft palate & 0 & 7.53 & 7.82 & 7.04 & 7.3 \\
Spleen & 0 & 7.08 & 6.58 & 7.05 & 7.54 \\
Tongue & 0 & 7.31 & 8.27 & 8.06 & 8.72 \\
Tonsil & 0 & 8.5 & 7.2 & 8.22 & 7.72 \\
\hline
\end{tabular}

* uninfected lamb killed as a control and tissues collected for analysis.

** lamb found dead at 5 dpi.

$\dagger$ viral RNA loads in tissues were quantified by real-time RT-PCR and expressed as $\log _{10}$ copy number per $g$ tissue dpi: days post maternal inoculation at the day the lambs were killed

LN: lymph node 
Figure 1: Graphs showing FMDV RNA levels in serum samples and temperature measurements from ewes inoculated with FMDV.

Figure 2: Graphs showing FMDV RNA levels in serum samples and temperature measurements from ewes kept in direct contact with FMDV-inoculated lambs.

Figure 3: Graphs showing FMDV RNA levels in serum samples and temperature measurements from lambs inoculated with FMDV.

Figure 4: Graphs showing FMDV RNA levels in serum samples and temperature measurements from lambs kept in direct contact with FMDV-inoculated ewes.

Figure 5: Histological sections of heart stained with haematoxylin and eosin. (a) and (b): Sections from lamb L38 (contact-infected, died $5 \mathrm{dpi}$ ) showing 40x and 63x views of a focus of perivascular lymphocyte and plasma cell aggregation. Myocardiocytes are dispersed and disrupted. (c) Section from lamb LA81 (inoculated, killed 4 dpi) showing 10x view of a poorly demarcated area plasmocytic-lymphocytic aggregation within myocardium; (d) 40x view of area of mononuclear inflammation with myocardiocyte disruption, also from LA81. Foci dominated by myocardiocyte swelling sometimes with hyalinisation, but with less marked inflammatory cell aggregation were also recognised (though are not shown in these photographs). 
61 Figure 6: ISH performed on heart (a: 10x view, b: 63x view) and skeletal muscle (c:

62 10x view, d: 40x view) sections from lamb L38, (contact-infected, died 5 dpi).

Figure 7: ISH performed on tongue and coronary band sections. (a) and (b): Tongue from lamb LA77 (inoculated, killed 4 dpi), 10x and 63x views respectively. (c): Tongue from lamb LA76 (inoculated, killed 2 dpi), 10x view; (d) coronary band from LA76, 10x view. Positive signal can be seen diffusely distributed throughout the basal zone of the tongue lesions, and in the subcorneal area of the coronary band lesion.

Figure 8: Graphs showing ratios of positive to negative strand viral RNA transcripts in tissues from lambs. (a) Data from inoculated lambs; (b) data from contact-infected lambs. A lower ratio indicates active replication. Where no ratio is shown for a sample, no negative strand RNA was detected, indicating little or no viral replication. CB: coronary band; CLN/MLN: cervical/mandibular lymph node. 


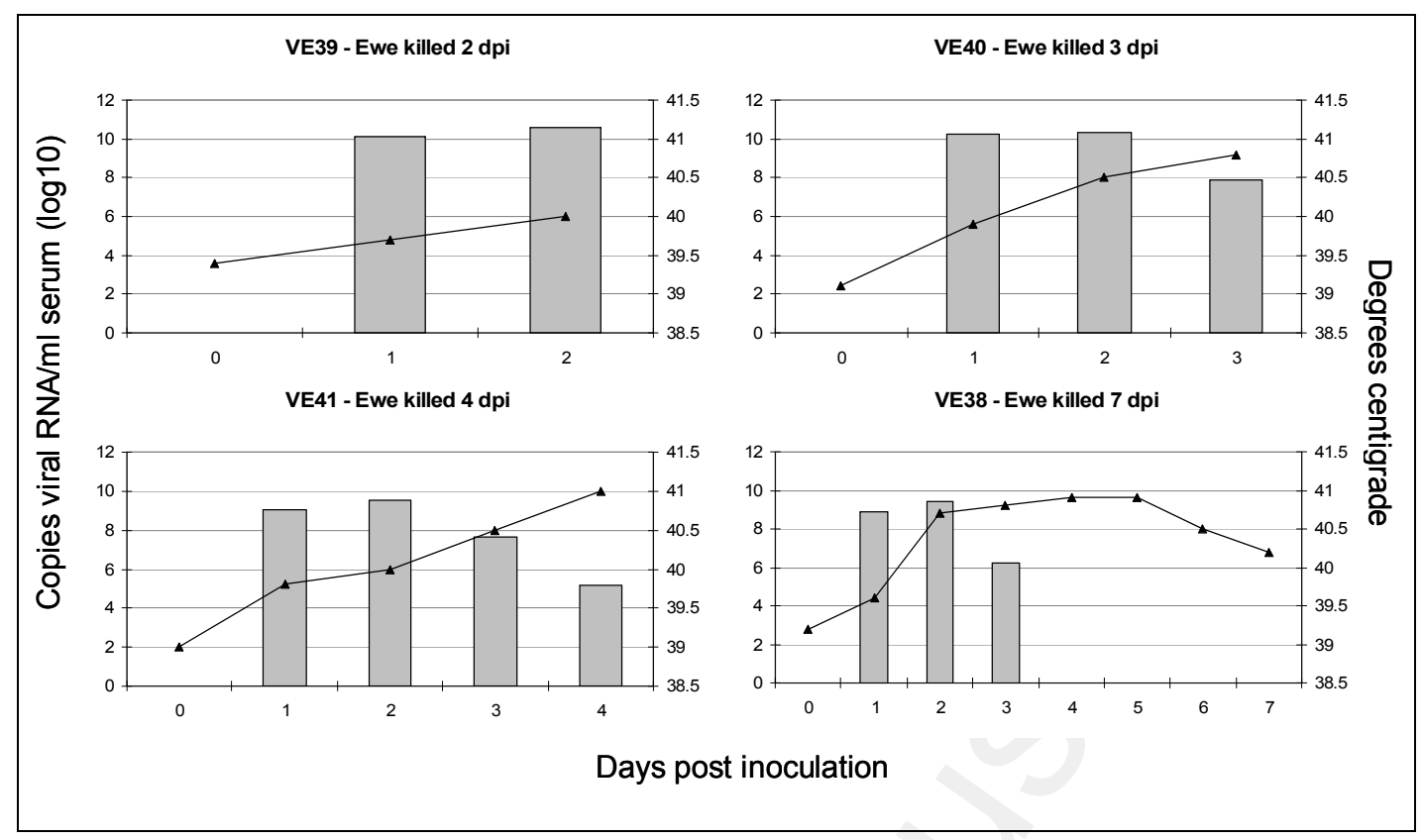

Figure 1: Graphs showing FMDV RNA levels in serum samples and temperature measurements from ewes inoculated with FMDV. FMDV RNA loads in serum samples are expressed as $\log _{10}$ copy number per $\mathrm{ml}$. 


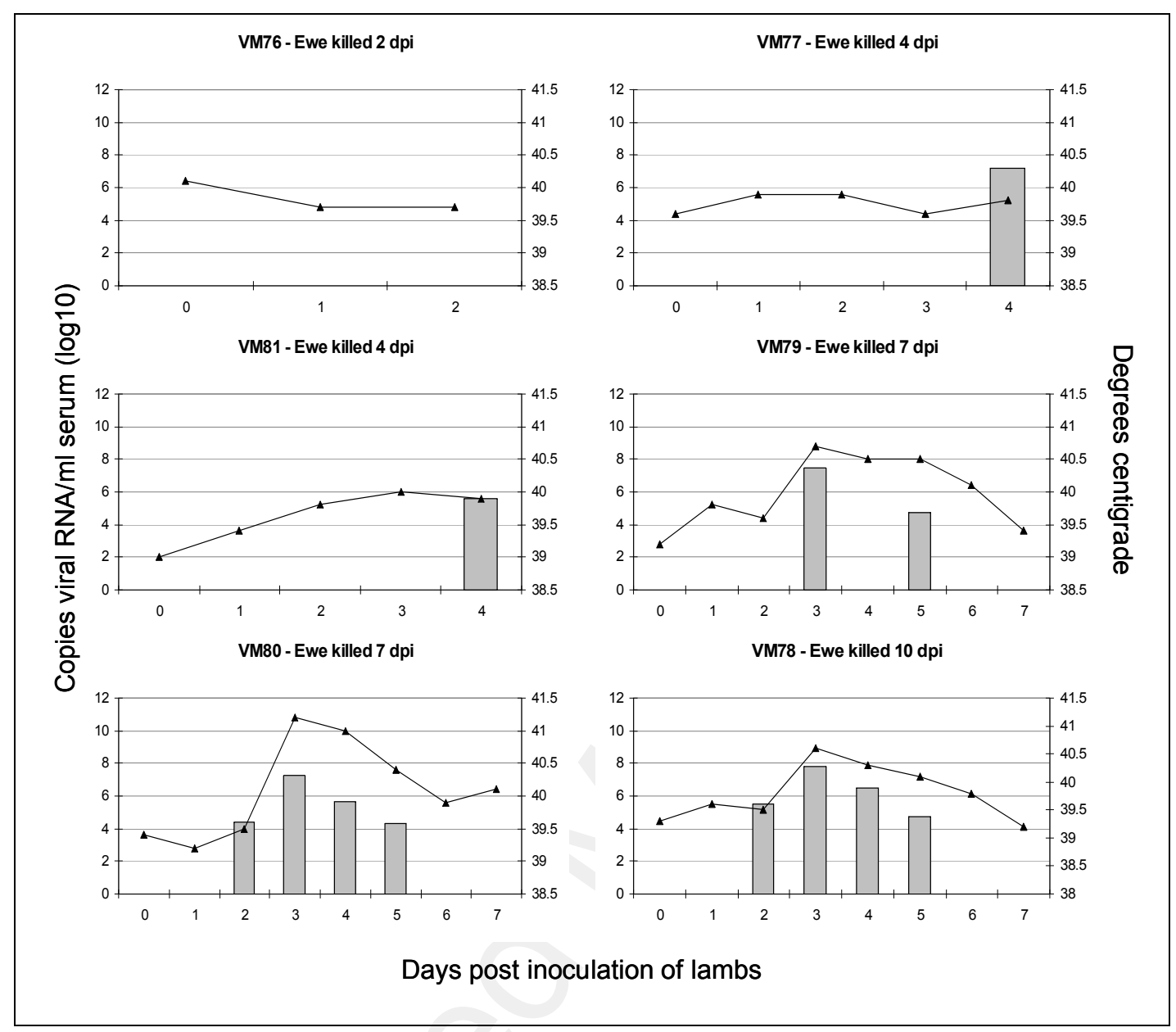

Figure 2: Graphs showing FMDV RNA levels in serum samples and temperature measurements from ewes kept in direct contact with FMDV-inoculated lambs. FMDV RNA loads in serum samples are expressed as $\log _{10}$ copy number per $\mathrm{ml}$ 


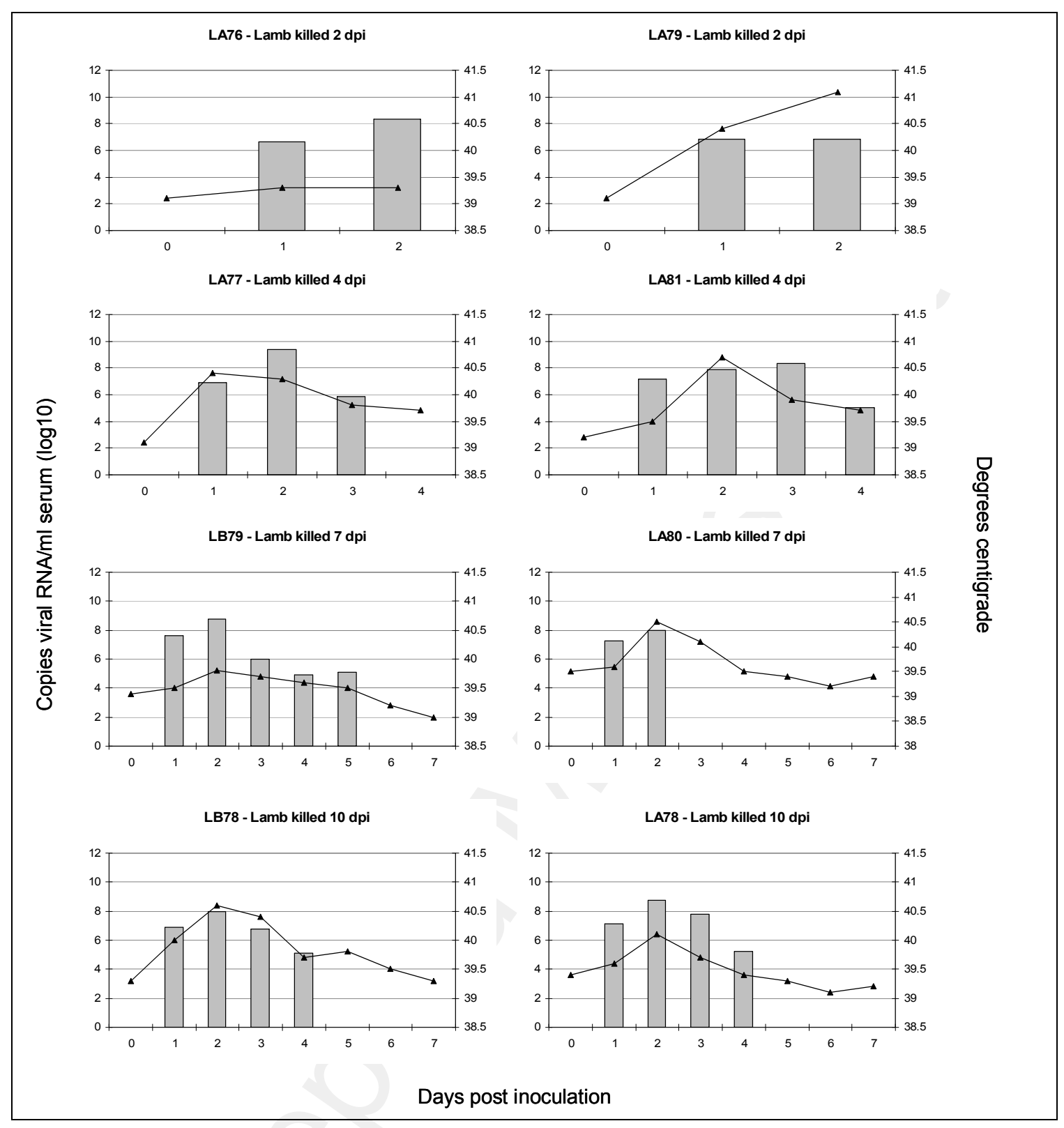

Figure 3: Graphs showing FMDV RNA levels in serum samples and temperature measurements from lambs inoculated with FMDV. FMDV RNA loads in serum samples are expressed as $\log _{10}$ copy number per $\mathrm{ml}$ 


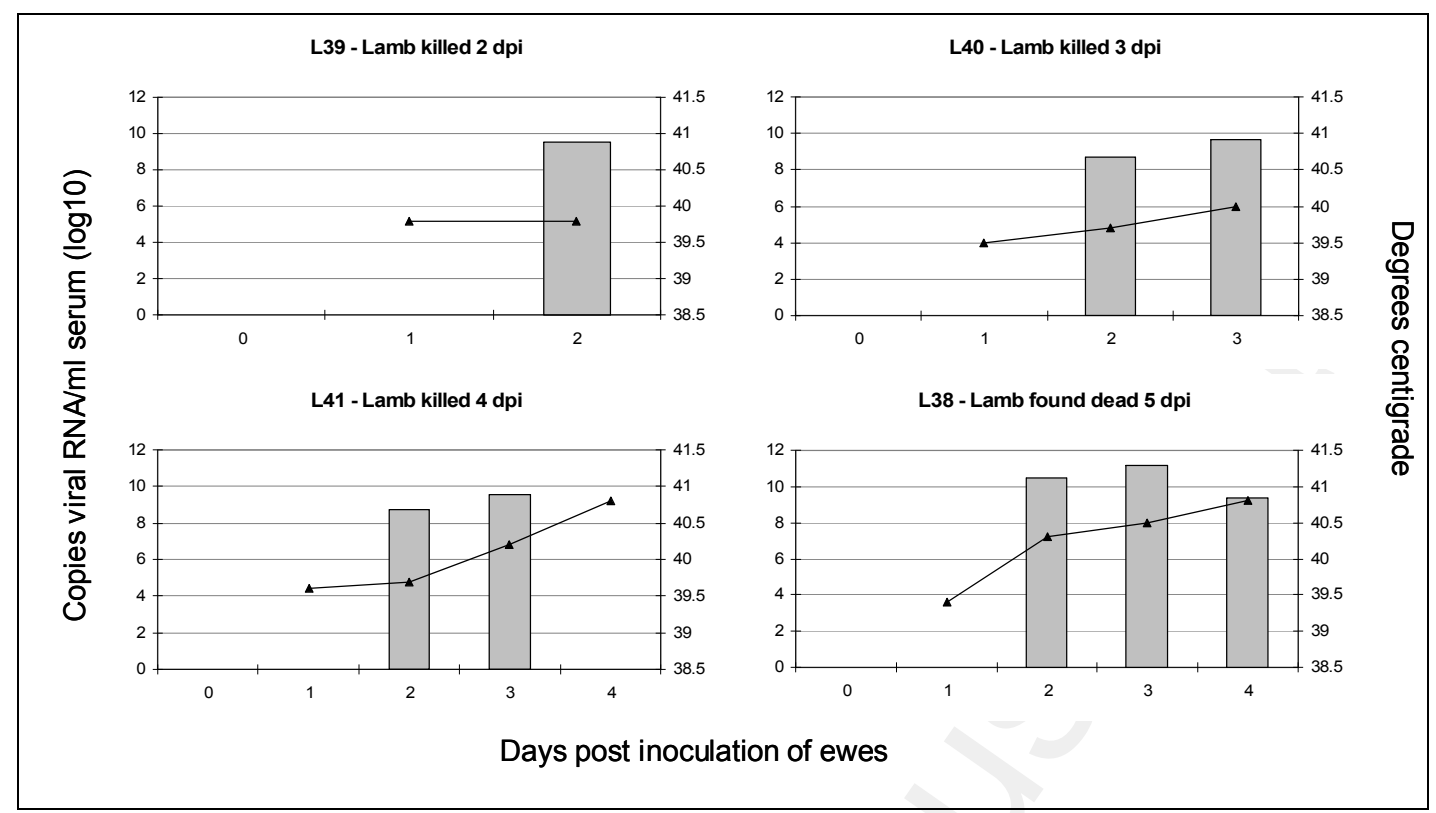

Figure 4: Graphs showing FMDV RNA levels in serum samples and temperature measurements from lambs kept in direct contact with FMDV-inoculated ewes. FMDV RNA loads in serum samples are expressed as $\log _{10}$ copy number per $\mathrm{ml}$ 


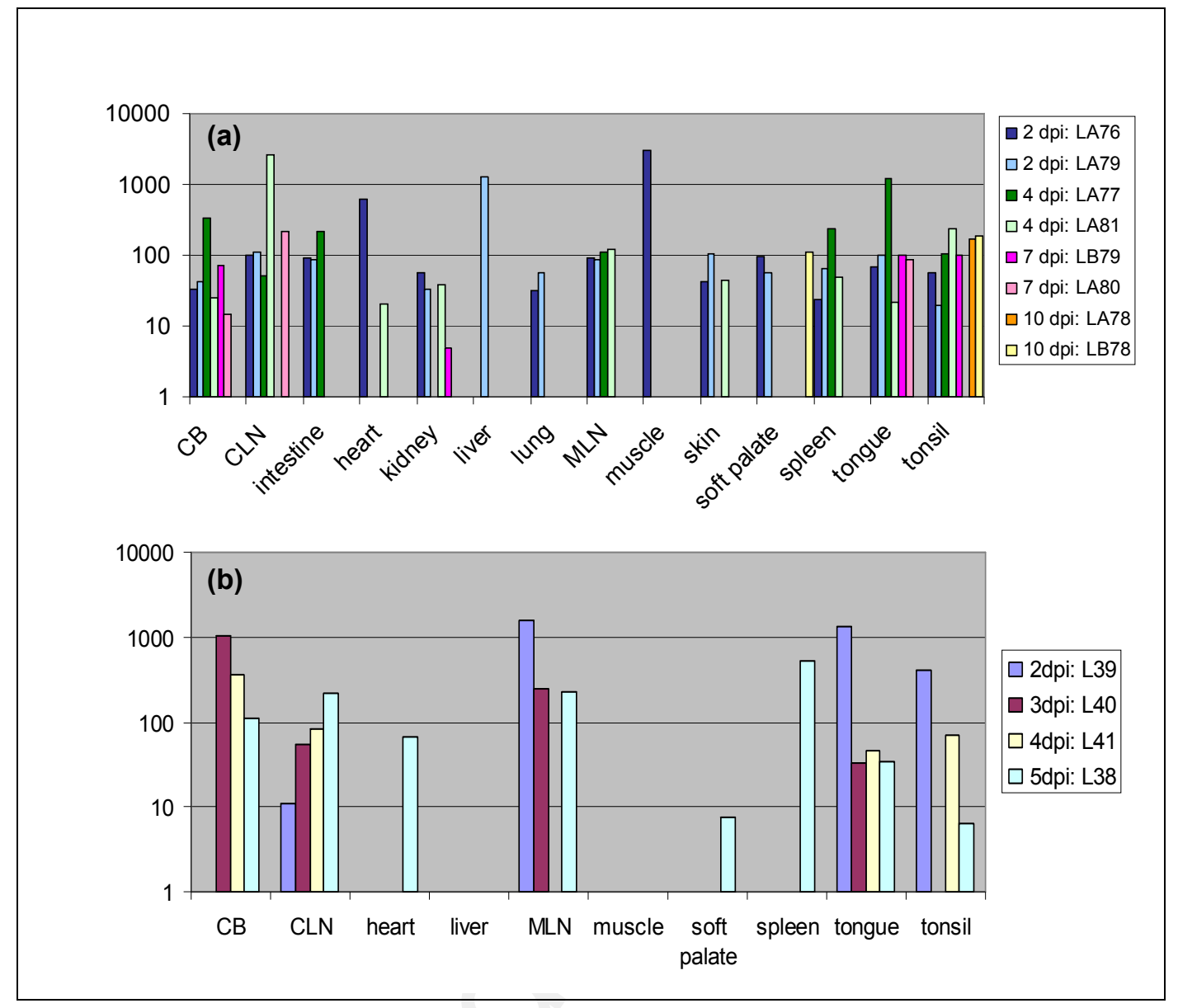

Figure 8: Graphs showing ratios of positive to negative strand viral RNA transcripts in tissues from lambs. (a) Data from inoculated lambs; (b) data from contact-infected lambs. A lower ratio indicates active replication. Where no ratio is shown for a sample, no negative strand RNA was detected, indicating little or no viral replication. CB: coronary band; CLN/MLN: cervical/mandibular lymph node. 

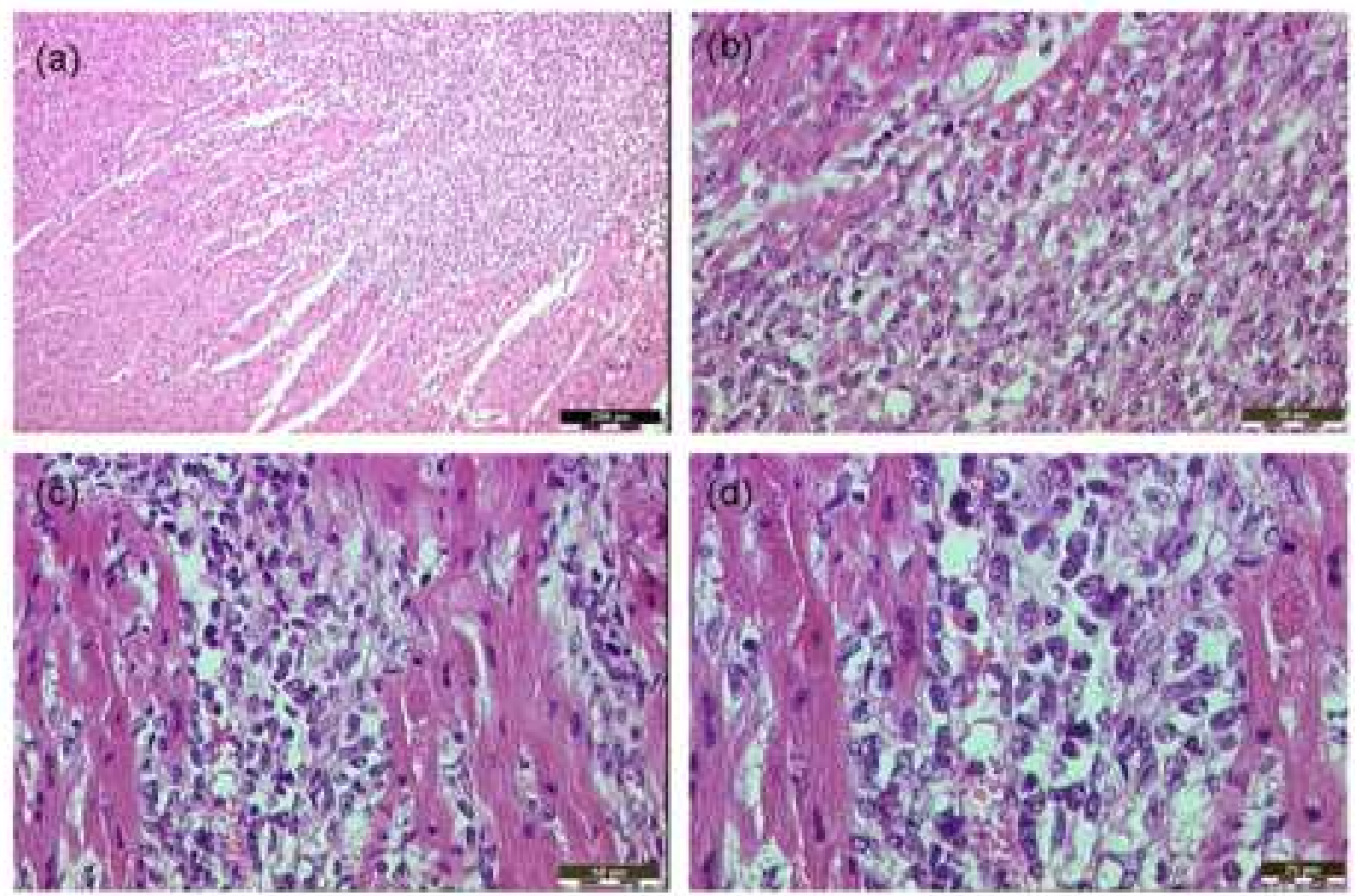

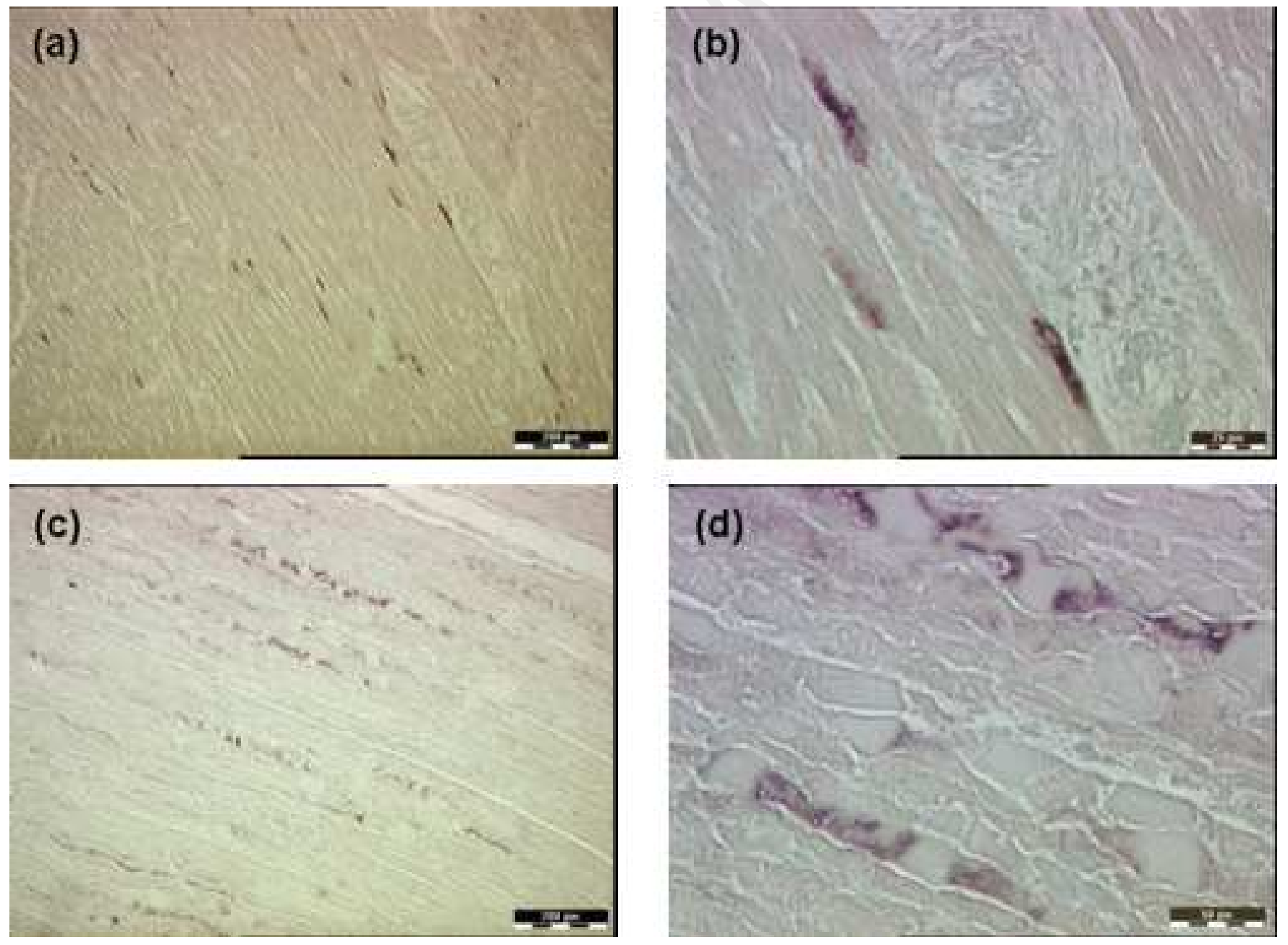

Page 40 of 41 

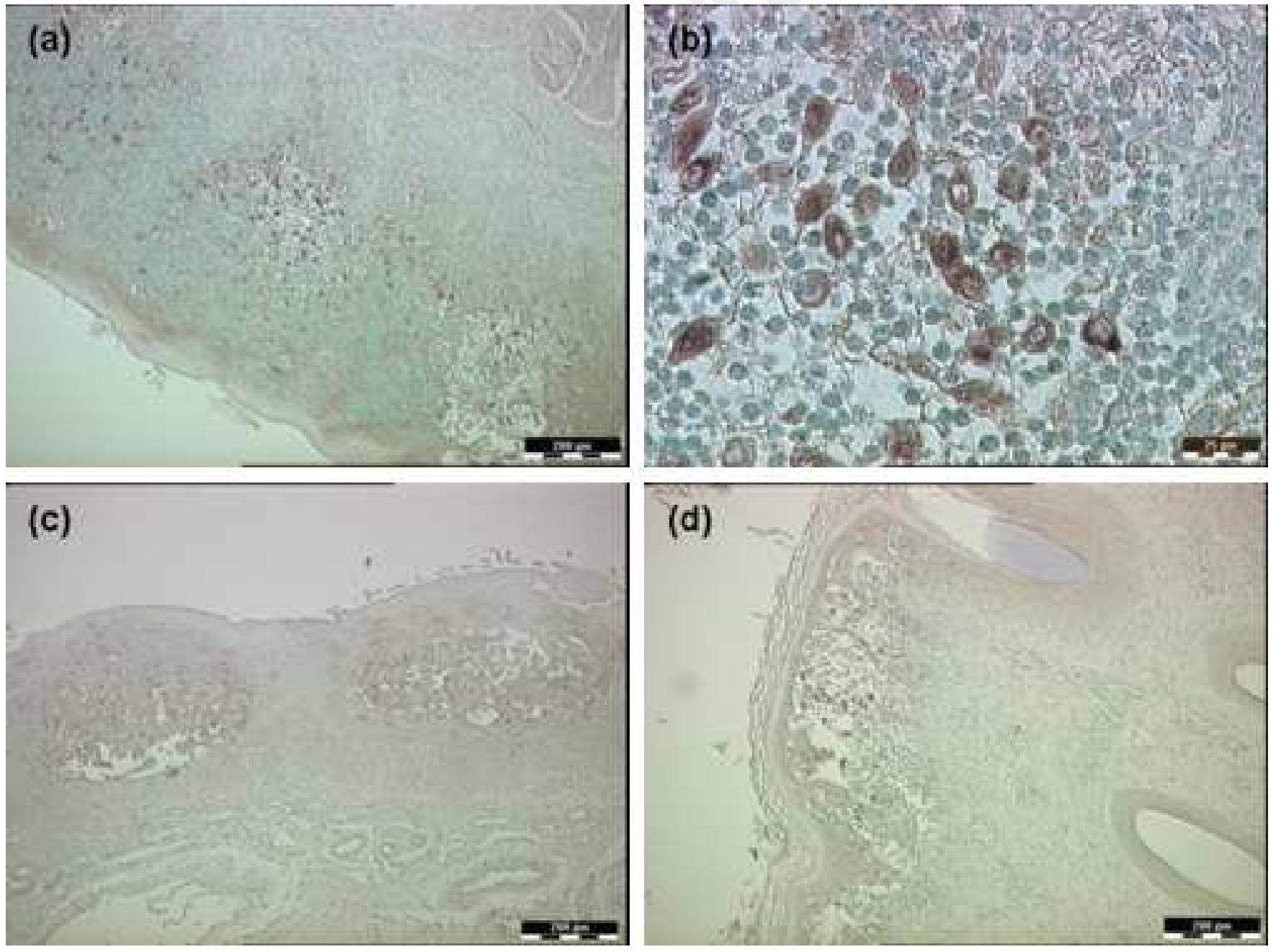

Page 41 of 41 